Pendas : Jurnal IImiah Pendidikan Dasar,

ISSN Cetak : 2477-2143 ISSN Online : 2548-6950

Volume III Nomor 2, Desember 2018

\title{
PENERAPAN MODEL THINK TALK WRITE UNTUK \\ MENINGKATKAN KETERAMPILAN SISWA DALAM \\ MENULIS KARANGAN DESKRIPSI DI SEKOLAH DASAR
}

\author{
Panji Maulana ${ }^{1}$ \\ PGSD STKIP SEBELAS APRIL \\ ${ }^{1}$ panjistkip@gmail.com \\ 2 MT Hartono Ikhsan \\ PGSD STKIP SEBELAS APRIL \\ ²hartono.ikhsan2781@gmail.com
}

\begin{abstract}
The problem in this study was the low learning activities and writing skills of fourth grade students of Cimanggung Elementary School in Cimanggung District, Sumedang Regency. This study aims to determine the increase in student learning activities, teacher teaching activities, and writing essay writing skills of class IV students using the Think Talk Write model. The instruments used in this study are observation sheets of student learning activities, teacher activity observation sheets, and tests. The purpose of this study is to improve the ability to write essays and student learning activities, describe the steps and processes / implementation of writing essay learning by applying the model TTW (Think Talk Write) learning, and describe whether there is an increase in the ability to write essays by applying the TTW (Think Talk Write) learning model to fourth grade students of Cimanggung Elementary School in Cimanggung District, Sumedang Regency. The research method used is PTK (Class Action Research) with the research design used refers to the model developed by Kemmis and Taggart, namely a spiral model that begins with: 1) planning (planning); 2) action / action (acting); 3) observation (observing); and 4) reflection (reflecting). The research subjects were 30th grade students at SDN Cimanggung, consisting of 15 women and 15 men. This study was conducted for 2 cycles. The results of the study are, 1) The use of think talk write model can improve student learning activities in writing description essays, 2) The use of think talk write models can also increase teacher activities, and 3) Use of think talk write models can also improve student learning outcomes in writing essay description.
\end{abstract}

Keywords: think talk models write, write, essays description

\begin{abstract}
ABSTRAK
Masalah dalam penelitian ini adalah rendahnya aktivitas belajar dan keterampilan menulis siswa kelas IV SDN Cimanggung Kecamatan Cimanggung Kabupaten Sumedang. Penelitian ini bertujuan untuk mengetahui peningkatan aktivitas belajar siswa, aktivitas mengajar guru, dan keterampilan menulis karangan deskripsi siswa kelas IV dengan menggunakan model Think Talk Write. Adapun instrumen yang digunakan dalam penelitian ini adalah lembar observasi aktivitas belajar siswa, lembar observasi aktivitas guru, dan tes .Tujuan penelitian ini yaitu untuk meningkatkan kemampuan menulis karangan dan aktivitas belajar siswa,
\end{abstract}


Pendas : Jurnal IImiah Pendidikan Dasar, ISSN Cetak : 2477-2143 ISSN Online : 2548-6950 Volume III Nomor 2, Desember 2018

mendeskripsikan langkah-langkah dan proses/pelaksanaan pembelajaran menulis karangan dengan menerapkan model pembelajaran TTW (Think Talk Write), dan mendeskripsikan ada tidaknya peningkatan kemampuan menulis karangan dengan menerapkan model pembelajaran TTW (Think Talk Write) pada siswa kelas IV SDN Cimanggung Kecamatan Cimanggung Kabupaten Sumedang. Metode penelitian yang digunakan adalah PTK (Penelitian Tindakan Kelas) dengan desain penelitian yang digunakan mengacu kepada model yang dikembangkan oleh Kemmis dan Taggart, yaitu model spiral yang dimulai dengan : 1) perencanaan (planning); 2) aksi/tindakan (acting); 3) observasi (observing); dan 4) refleksi (reflecting). Subjek penelitian adalah siswa kelas IV SDN Cimanggung yang berjumlah 30 orang, terdiri dari 15 orang perempuan dan 15 orang laki-laki. Penelitian ini dilakukan selama 2 siklus. Hasil penelitian yaitu, 1) Penggunaan model think talk write dapat meningkatkan aktivitas belajar siswa dalam menulis karangan deskripsi, 2) Penggunaan model think talk write juga dapat meningkatkan aktivitas guru, dan 3) Penggunaan model think talk write juga dapat meningkatkan hasil belajar siswa dalam menulis karangan deskripsi.

Kata Kunci: model think talk write, menulis, karangan deskripsi

\section{A. PENDAHULUAN}

Berdasarkan hasil observasi awal yang penulis lakukan di SDN Cimanggung Sumedang, terdapat beberapa permasalahan dalam pembelajaran bahasa Indonesia khususnya dalam menulis karangan deskripsi. Masalah tersebut adalah penggunakan metode pembelajaran yang kurang variatif, siswa kurang antusias dalam pembelajaran, minat siswa dalam menulis kurang, dan kurangnya fasilitas yang memadai untuk menunjang pembelajaran sehingga proses belajar mengajar kurang optimal. Siswa kurang antusias dalam pembelajaran, siswa belum mampu menuangkan gagasan, pendapat, maupun idenya ke dalam bentuk tulisan. Kemudian pada kegiatan kelompok siswa cenderung mengerjakan secara individual sehingga tidak terbentuk partisipasi dalam suatu kelompok, kurangnya media pendukung dalam proses pembelajaran, serta guru kurang menggunakan model-model pembelajaran yang bervariasi sehingga siswa kurang aktif dan merasa bosan. Hal ini berdampak pada hasil belajar siswa.

Untuk mengatasi masalah tersebut guru harus mampu menciptakan suasana pembelajaran yang menyenangkan. Hal ini disebabkan karena kegiatan pembelajaran yang menyenangkan dapat tercipta apabila guru menggunakan model pembelajaran yang bervariasi dan media 
Pendas : Jurnal Ilmiah Pendidikan Dasar, ISSN Cetak : 2477-2143 ISSN Online : 2548-6950 Volume III Nomor 2, Desember 2018

pembelajaran yang sesuai dengan materi bahasa Indonesia yang akan diajarkan disesuikan dengan karakteristik siswanya. Oleh karena itu, pembelajaran akan menjadi lebih bermakna dan tujuan pembelajaran bahasa Indonesia dapat tercapai. Berdasarkan data pencapaian hasil belajar yang diperoleh dari nilai ulangan harian tentang keterampilan menulis karangan deskripsi pada mata pelajaran bahasa Indonesia yang belum mencapai KKM.

Berdasarkan diskusi bersama kolaborator serta berlandaskan pada teori konstruktivisme, didalam memecahkan masalah tersebut peneliti dan kolaborator menetapkan alternatif dengan menerapkan model think talk write dengan media visual. Model think talk write merupakan model pembelajaran didasarkan pada pemahaman bahwa belajar adalah sebuah perilaku sosial. Dalam model pembelajaran ini, siswa didorong untuk berpikir, berbicara, dan menuliskan berkenaan dengan suatu topik. Metode ini merupakan metode yang dapat melatih kemampuan berpikir dan menulis siswa. Model think talk write dalam pembelajaran menulis karangan deskripsi memiliki kelebihan yaitu: (1) siswa menjadi lebih kritis: (2) semua siswa lebih aktif dalam proses pembelajaran; dan (3) siswa lebih paham terhadap materi yang dipelajari.

Kegiatan menulis karangan deskripsi dengan think talk write akan lebih optimal apabila ditunjang dengan media pembelajaran. Peneliti memilih media visual untuk menunjang pembelajaran dengan model thik talk write. Media visual merupakan semua alat peraga yang digunakan dalam proses belajar yang bisa dinikmati lewat panca-indera mata oleh Daryanto (1993:27). Kelebihan media visual yaitu: (1) lebih menarik karena ada gambar, sehingga memberikan pengalaman nyata untuk siswa; (2) lebih mudah mengingat dengan visual peta konsep, maid mapping dan singkatan; (3) media visual dapat memperlancar dengan pemahaman (misalnya melalui elaborasi struktur dan organisasi) dan memperkuat ingatan siswa; dan (4) visual dapat pula menumbuhkan minat siswa dan dapat memberikan hubungan antara isi materi pelajaran dengan dunia nyata. 
Pendas : Jurnal Ilmiah Pendidikan Dasar, ISSN Cetak : 2477-2143 ISSN Online : 2548-6950 Volume III Nomor 2, Desember 2018

\section{B.LANDASAN TEORI}

\section{Model Think Talk Write}

Think Talk Write (TTW) merupakan model pembelajaran yang dikembangkan oleh Huinker dan Laughlin. Model pembelajaran think talk write (TTW) didasarkan pada pemahaman bahwa belajar adalah sebuah perilaku sosial. Dalam model pembelajaran ini, siswa didorong untuk berpikir, berbicara, dan kemudian menuliskan berkenaan dengan suatu topik. Metode ini merupakan metode yang dapat melatih kemampuan berpikir dan menulis siswa.

Model pembelajaran think talk write didesain untuk meningkatkan rasa tanggung jawab siswa terhadap pembelajarannya sendiri dan juga pembelajaran orang lain. Siswa tidak hanya mempelajari materi yang diberikan tetapi mereka juga harus siap membagi ide dan mengajarkan materi tersebut pada anggota kelompoknya.

Para anggota kelompok diminta membaca, membuat catatan kecil, menjelaskan, mendengarkan, dan membagi ide bersama teman atau menukarkan informasi apa yang telah ia pelajari sehingga saling melengkapi dalam penguasaan materi atau wawasan mereka untuk mempelajari topik yang diberikan dan ditugaskan serta kemudian mengungkapkannya melalui tulisan.

Dalam teknik ini guru memperlihatkan skemata atau latar belakang pengalaman siswa dan membantu siswa mengaktifkan skemata ini agar bahan pelajaran menjadi menarik dan lebih bermakna. Selain itu, siswa bekerjasama dengan sesama siswa dalam suasana gotong royong dan mempunyai banyak kesempatan untuk mengolah informasi dan mampu meningkatkan keterampilan berkomunikasi.

Model pembelajaran think talk write dimulai dengan berpikir melalui bahan bacaan (menyimak, mengkritisi, dan alternatif solusi), hasil bacaannya dikomunikasikan dengan presentasi, diskusi dan kemudian buat laporan hasil presentasi. Pembelajaran TTW ini merupakan suatu tipe pembelajaran kooperatif yang terdiri dari beberapa anggota dalam satu kelompok yang bertanggungjawab atas penguasaan bagian materi belajar dan mampu mengajarkan materi tersebut kepada anggota dalam kelompoknya secara heterogen dan bekerja sama saling 
Pendas : Jurnal Ilmiah Pendidikan Dasar, ISSN Cetak : 2477-2143 ISSN Online : 2548-6950 Volume III Nomor 2, Desember 2018

ketergantungan yang positif dan bertanggung jawab atas ketuntasan bagian materi pelajaran yang harus dipelajari dan menyampaikan materi kepada anggota kelompoknya sehingga didesain untuk meningkatkan rasa tanggungjawab siswa terhadap pembelajarannnya sendiri dan juga pembelajaran orang lain. Siswa tidak hanya mempelajari materi yang diberikan, tetapi harus siap memberikan dan mengajarkan materi tersebut pada anggota kelompoknya.

\section{Keterampilan Menulis}

Menulis merupakan salah satu keterampilan berbahasa yang dipergunakan dalam komunikasi secara tidak langsung. Keterampilan menulis tidak didapatkan secara alamiah, tetapi harus melalui proses belajar dan berlatih. (Doyin dan Wagiran, 2009:12). Sedangkan Tarigan (1986:15) menyatakan bahwa menulis adalah kegiatan menuangkan ide/gagasan dengan menggunakan bahasa tulis sebagai media penyampai kepada pembaca. Selain itu, menulis juga dikemukakan oleh Iskandarwassid (2008:248) yang menyatakan bahwa aktivitas menulis merupakan suatu bentuk manifestasi kemampuan dan keterampilan berbahasa yang paling akhir dikuasai oleh pembelajar setelah kemampuan mendengarkan, berbicara, dan membaca.

Berdasarkan pengertian di atas, dapat disimpulkan bahwa menulis merupakan kemampuan didalam mengeluarkan gagasan/ide secara komunikasi tidak langsung yang bertujuan untuk memberitahu kepada seseorang.

\section{Aktivitas Belajar Siswa}

Perilaku siswa dalam pembelajaran diartikan sebagai aktivitas siswa. Aktivitas siswa dalam pembelajaran merupakan segala kegiatan yang dilakukan siswa dalam proses interaksi (guru dan siswa) pada pembelajaran untuk memperoleh perubahan tingkah laku. Aktivitas siswa dalam pembelajaran sangat penting, sebab dengan adanya aktivitas siswa dalam proses pembelajaran terciptalah situasi belajar aktif (Depdiknas, 2006:31).

Dierich (dalam Sardiman, 2011:101) menyimpulkan terdapat 177 kegiatan peserta didik yang meliputi aktivitas jasmani dan aktivitas jiwa, antara lain sebagai berikut.

1. Visual activities meliputi kegiatan membaca,memperhatikan gambar, 
Pendas : Jurnal Ilmiah Pendidikan Dasar, ISSN Cetak : 2477-2143 ISSN Online : 2548-6950 Volume III Nomor 2, Desember 2018

demonstrasi, percobaan, dan pekerjaan orang lain.

2. Oral activities, yaitu meliputi kegiatan menyatakan,kegiatan merumuskan, bertanya, memberi saran, mengelurkan pendapat, mengadakan interview, diskusi, dan interupsi.

3. Listening activities, meliputi kegiatan mendengarkan uraian, percakapan, diskusi, musik, dan pidato.

4. Writing activities, meliputi menulis cerita, karangan, laporan, tes angkat, dan menyalin.

5. Drawing activities meliputi menggambar, membuat grafik, peta, diagram, dan pola.

6. Motor activities meliputi kegiatan melakukan percobaan, membuat konstruksi, model, mereparasi, bermain, kegiatan berkebun, dan memelihara binatang.

7. Mental activities meliputi kegiatan menganggap, kegiatan mengingat, memecahkan suatu masalah, menganalisa, melihat hubungan, mengambil keputusan.

8. Emotional activies, meliputi menaruh minat, merasa bosan, gembira, bersemangat, bergairah, berani, tenang, dan gugup.
Jadi, aktivitas belajar siswa adalah segala kegiatan yang dilakukan oleh siswa yang dapat menunjang keterampilan menulis siswa pada pembelajaran bahasa Indonesia melalui model think talk write.

\section{METODE PENELITIAN}

Metode yang digunakan dalam penelitian ini adalah penelitian tindakan kelas (classroom action research) yaitu suatu bentuk penelitian yang dilakukan oleh guru di kelasnya sendiri secara kolaboratif dan partisipatif dengan tujuan untuk memperbaiki kinerjanya sebagai guru sehingga prestasi belajar siswa dapat meningkat. Dengan kata lain, penelitian tindakan kelas bertujuan untuk memecahkan masalahmasalah setempat suatu sekolah atau lebih khusus lagi pada pembelajaran tertentu dan di suatu kelas tertentu dengan menggunakan metode ilmiah.

Menurut Arikunto (2006: 20), "Penelitian tindakan kelas tidak pernah merupakan kegiatan tunggal, tetapi harus berupa rangkaian kegiatan yang akan kembali ke asal sehingga membentuk suatu siklus". Oleh sebab itu model penelitian 
Pendas : Jurnal Ilmiah Pendidikan Dasar, ISSN Cetak : 2477-2143 ISSN Online : 2548-6950 Volume III Nomor 2, Desember 2018

tindakan kelas yang digunakan dalam penelitian ini adalah model penelitian yang dikembangkan oleh Kemmis dan Mc. Taggart yaitu model penelitian yang menggunakan sistem spiral refleksi yang terdiri dari beberapa siklus. Tiap siklus dimulai dari rencana (planning), kemudian tindakan (acting), dilanjutkan dengan observasi (observing) dari tindakan yang telah dilakukan, dan yang terakhir adalah refleksi (reflecting). Setiap tahapan tersebut berfungsi saling menguraikan karena pada masing-masing tahapan meliputi proses penyempurnaan yang harus dilaksanakan secara terus menerus sehingga mendapatkan hasil yang diinginkan. Adapun dalam penelitian ini, peneliti akan melaksanakan tiga siklus yang mencakup satu pokok bahasan utuh dalam mata pelajaran Bahasa Indonsia kelas IV SDN Cimanggung Kabupaten Sumedang. Secara skematis, siklus pembelajaran yang peneliti laksanakan dalam penelitian tindakan kelas ini adalah seperti pada bagan berikut.

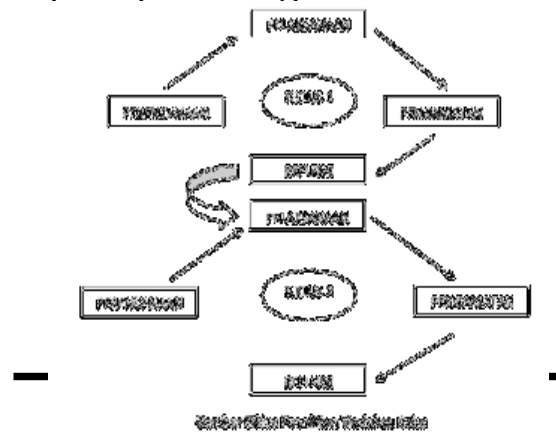

Untuk menunjang kelancaran proses pembelajaran di kelas, dalam penelitian ini peneliti menggunakan prinsip-prinsip penelitian tindakan kelas yaitu: (a) tidak mengganggu komitmen mengajar, (b) pelaksanaan penelitian tidak mengubah jadwal yang sudah ada sebelumnya di sekolah, (c) metode pemecahan masalah reliabel karena pendekatan yang digunakan merupakan pendekatan yang pernah digunakan oleh peneliti lain sebelumnya, (d) permasalahan diangkat dengan berorientasi pemecahan masalah guru dalam tugas keseharian. Dengan menerapkan prinsip-prinsip tersebut diharapkan penelitian ini dapat berjalan dengan lancar dan menghasilkan perbaikan proses pembelajaran sebelumnya.

\section{Setting Penelitian}

Prosedur yang ditempuh dalam melakukan penelitian ini adalah sebagai berikut:

1. Orientasi Lapangan (penelitian awal)

a. Observasi dan evaluasi kegiatan pembelajaran untuk memperoleh informasi mengenai pelaksanaan pembelajaran Bahasa Indonesia selama ini. 
Pendas : Jurnal IImiah Pendidikan Dasar, ISSN Cetak : 2477-2143 ISSN Online : 2548-6950 Volume III Nomor 2, Desember 2018

b. Wawancara dengan pihak sekolah. Dilakukan untuk memperoleh informasi tentang gambaran pelaksanaan pembelajaran dan kendala yang dihadapi dalam pembelajaran Bahasa Indonesia.

c. Mengidentifikasi masalah-masalah pembelajaran yang terdapat di sekolah tempat penelitian.

2. Tahap Persiapan

a. Menetapkan pokok bahasan yang akan dipergunakan dalam penelitian. Hal ini dilakukan untuk mempermudah peneliti dalam dalam menyusun instrumen penelitian.

b. Merancang dan menyusun suatu rencana kegiatan pelaksanaan pembelajaran yang akan dilakukan sehingga proses pembelajaran dapat lebih terarah untuk mencapai tujuan pembelajaran.

c. Menyusun instrumen penelitian. Instrumen penelitian berfungsi untuk merekam semua data-data yang dibutuhkan sehingga instrumen penelitian harus disusun secara baik.

d. Konsultasi instrumen kepada dosen pembimbing, dilakukan agar instrumen yang dibuat memiliki kualitas yang baik.

e. Merevisi instrumen jika diperlukan
3. Tahap Pelaksanaan

a. Melaksanakan pembelajaran dengan menggunakan pendekatan kontekstual komponen pemodelan

b. Melakukan tes formatif pada akhir pembelajaran setiap siklus. Untuk mendapatkan data prestasi belajar yang didapat siswa dalam pembelajaran dalam setiap siklus yang terdiri dari beberapa kali pertemuan maka dilakukan tes formatif.

c. Melakukan tes subsumatif setelah semua siklus berakhir. Untuk melengkapi data prestasi belajar yang diperoleh siswa hasil tes formatif maka di akhir semua siklus diadakan tes subsumatif yang materi soalnya berasal dari semua materi pelajaran yang telah diberikan pada semua proses pembelajaran pada semua siklus.

d. Melakukan wawancara dengan siswa mengenai pembelajaran berbasis masalah terstruktur. Wawancara dilakukan kepada perwakilan dari setiap kelompok siswa.

4. Analisis dan refleksi

Data yang diperoleh dianalisis sesegera mungkin berdasarkan kriteria-kriteria yang telah ditetapkan. Setelah dianalisis 
Pendas : Jurnal Ilmiah Pendidikan Dasar, ISSN Cetak : 2477-2143 ISSN Online : 2548-6950

Volume III Nomor 2, Desember 2018

kemudian direfleksikan sebagai bahan evaluasi dan koreksi untuk memperbaiki siklus berikutnya

5. Membuat kesimpulan hasil penelitian.

\section{Subjek Penelitian}

Penelitian dilakukan pada siswa kelas IV SDN Cimanggung Kecamatan Cimanggung Kabupaten Sumedang yang berjumlah 30 orang. Terdiri dari 15 laki-laki dan 15 perempuan.

\section{Teknik Pengumpulan Data}

Metode pengumpulan data menggunakan beberapa instrumen yaitu sebagai berikut.

\section{Tes}

Tes digunakan untuk memperoleh data tentang hasil belajar siswa dalam penerapan model pembelajaran TTW dalam pembelajaran menulis karangan deskripsi.

\section{Observasi}

Observasi digunakan untuk meperoleh data tentang aktivitas guru dan siswa dalam pelaksanaan model pembelajaran TTW dalam pembelajaran menulis karangan deskripsi.

\section{Wawancara}

Wawancara dilakukan untuk
mengumpulkan data dengan

melibatkan nara sumber dalam

mengungkapkan idea tau pendapat yang disampaikan secara lisan/ tulisan dalam bentuk angket mengenai proses pembelajaran yang berlangsung di kelas.

\section{HASIL DAN PEMBAHASAN}

Berdasarkan hasil analisis data, pembahasan hasil penelitian, dan temuan-temuan penulis di lapangan diperoleh informasi sebagai berikut.

1. Penggunaan model think talk write dapat meningkatkan aktivitas belajar siswa dalam menulis karangan deskripsi. Berdasarkan hasil observasi pada siklus I jumlah skor aktivitas belajar siswa mencapai 29 dengan rata-rata 72,5 (baik). Meningkat pada siklus II menjadi 37 dengan rata-rata 92,5 (sangat baik). Penggunaan model think talk write dengan baik dan benar terbukti dapat meningkatkan aktivitas belajar siswa dalam pembelajaran menulis karangan deskripsi.

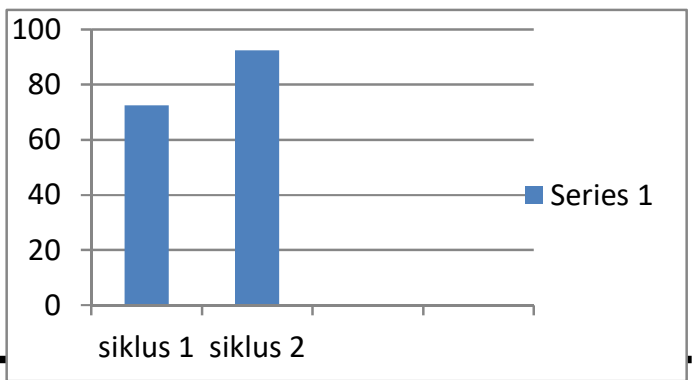


Pendas : Jurnal Ilmiah Pendidikan Dasar, ISSN Cetak : 2477-2143 ISSN Online : 2548-6950 Volume III Nomor 2, Desember 2018

2. Penggunaan model think talk write juga dapat meningkatkan aktivitas guru. Berdasarkan hasil observasi pada siklus I jumlah skor aktivitas guru mencapai 27 dengan ratarata 67,5 (baik). Meningkat pada siklus II menjadi 37 dengan ratarata 92,5 (sangat baik).

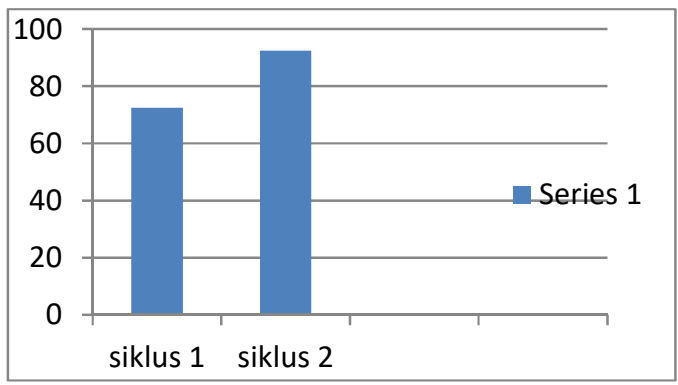

3. Penggunaan model think talk write juga dapat meningkatkan hasil belajar siswa dalam menulis karangan deskripsi. Pada siklus I nilai rata-rata siswa mencapai 75 dengan ketuntasan $80 \% \quad(24$ orang). Meningkat pada siklus II menjadi 78 dengan ketuntasan $93 \%$ (28 orang).

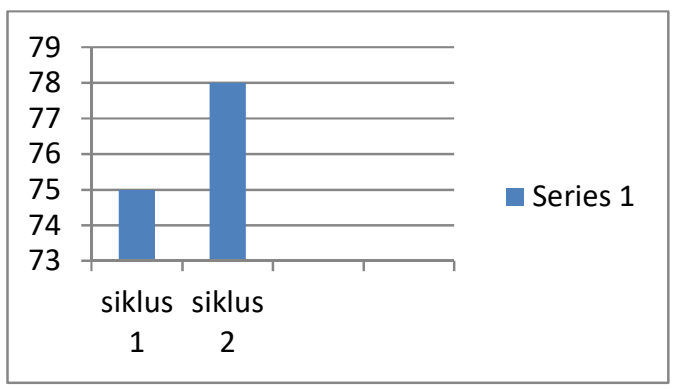

\section{E. KESIMPULAN}

Berdasarkan hasil temuan penelitian, didapatkan informasi bahwa 1) Penggunaan model think talk write dapat meningkatkan aktivitas belajar siswa dalam menulis karangan deskripsi, 2) Penggunaan model think talk write juga dapat meningkatkan aktivitas guru, dan 3) Penggunaan model think talk write juga dapat meningkatkan hasil belajar siswa dalam menulis karangan deskripsi.

Ssaran yang dapat penulis sampaikan sebagai berikut:

\section{Bagi Siswa}

a. Siswa harus mengikuti intruksi guru dalam setiap tahapan pembelajaran menulis karangan deskripsi dengan menggunakan model think talk write.

b. Siswa menjadi lebih aktif dalam mengemukakan ide, pendapat, dan memberikan tanggapan. Alangkah baiknya ide, pendapat, dan tanggapan tersebut disampaiakan secara logis dan tidak menyinggung kelompok lain,

\section{Bagi Guru}

a. Guru harus berusaha mengelompokan siswa dengan kemampuan yang merata, supaya 
Pendas : Jurnal Ilmiah Pendidikan Dasar, ISSN Cetak : 2477-2143 ISSN Online : 2548-6950 Volume III Nomor 2, Desember 2018

kegiatan pembelajaran terutama diskusi berjalan interaktif.

b. Guru harus memberikan penjelasan kepada siswa mengenai langkah-langkah penggunaan model think talk write, agar pembelajaran berjalan lancar dan siswa tidak kebingungan.

c. Dalam kegiatan diskusi, guru berperan sebagai fasilitator. Guru harus memberikan bimbingan secara maksimal kepada kelompok siswa yang mengalami kesulitan.

d. Untuk memaksimalkan penggunaan model think talk write, guru perlu menambah buku sumber/ referensi.

\section{Bagi Sekolah}

a. Pembelajaran menulis karangan deskripsi di SDN Cimanggung Kabupaten Sumedang perlu dikembangkan dan dilaksanakan bukan hanya di kelas IV saja, tetapi juga di kelas lainnya agar kemampuan siswa menjadi meningkat.

b. Pembelajaran menulis karangan merupakan salah satu cara meningkatkan keterampilan menulis. Untuk itu, perlu dikembangkan alternatif-alternatif lain sehinngga kemampuan siswa dalam menulis semakin meningkat dan kemampuan guru dalam memfasilitasi proses belajar menulis menjadi meningkat.

c. Model think talk write merupakan salah satu model pembelajaran menulis yang berdasarkan PTK terbukti dapat meningkatkan keterampilan siswa dalam menulis karangan deskripsi. Alangkah lebih baiknya jika kepala sekolah dan guru kelas berkenan untuk mengembangkan serta melaksanakan PTK ini untuk medapatkan kualitas pembelajaran yang lebih baik dan optimal.

\section{DAFTAR PUSTAKA}

Anitah, S,dkk. 2009. Strategi Pembelajaran di SD. Jakarta: Universitas Terbuka.

Anni, C, T. (2007). Psikologi Belajar. Semarang: Unnes Press.

Arifin, T. 2010. Cermat Berbahasa Indonesia. Jakarta: Akademika Pressindo.

Arsyad, A. 2011. Media pembelajaran. Jakarta: PT. Raja Grafindo Persada.

Arikunto, S. 2006. Prosedur penelitian suatu pendekatan praktik. Jakarta: Rineka Cipta. 
Pendas : Jurnal Ilmiah Pendidikan Dasar, ISSN Cetak : 2477-2143 ISSN Online : 2548-6950 Volume III Nomor 2, Desember 2018

Aqib, Z. 2009. Penelitian Tindakan Kelas untuk Guru SD,SLB,TK. Bandung:Yrama Widya.

Depdiknas. 2007 . Kajian kebijakan

Kurikulum Mata Pelajaran

Bahasa. Jakarta: Badan

Penelitian dan Pengembangan

Depdiknas.

DePorter, B dan Hernacki, M. (2012). Quantum Learning Membiasakan Belajar Nyaman dan Menyenangkan. Penerjemah Alwaliyah Abdurrachman. Bandung: Kaifa.

Doyin, W. 2011. Bahasa Indonesia.

Semarang: Unniversitas Negeri Semarang.

Dwihatmi, E, A. 2013. Peningkatan Keterampilan Menulis Karangan Deskripsi dengan menggunakan Model Think Talk Write. Semarang: Publikasi Unnes.

Febri, E. 2011. Asesmen dan evaluasi. Yogyakarta: Aditya Media Publishing

Iskandarwassid, S. 2008. Strategi pembelajaran bahasa. Bandung: Rosda.

Rosdiana,Y. 2008. Bahasa dan Sastra Indonesia di SD. Jakarta: Universitas Terbuka.
Sardiman, A, M. 2011. Interaksi Dan Motivasi Belajar Dan Mengajar. Jakarta: Raja Grafindo Persada.

Sufanti. 2010. Strategi Pengajaran Bahasa Dan Sastra Indonesia. Surakarta: Yuma Pustaka.

Suparno, Y. 2010. Keterampilan Dasar Menulis. Jakarta: Universitas Terbuka. 